\title{
The Collected Larkin: "But why put it into words?" . Peter Filkins
}

THE MAKING OF A SUPERB POET is as rare an event as the lasting gifts handed down to us in the shape of truly fine poems. Even more unique, however, is when we are given an open window onto the furnace room of creation, each movement of hammer and tongs, each tinkering adjustment of bellows and heat becomes artistry in itself as we stare at the forging of the well made thing, suddenly manifest and wholly beautiful, there for the ages.

Anthony Thwaite has provided just such an opportunity in his brilliant editing of Philip Larkin's Collected Poems. Here for the first time the course of Larkin's apprenticeship is made apparent through the inclusion of eighty-three poems never before published. On top of this, Thwaite shows a stroke of genius himself by arranging the poems, both published and unpublished, according to their date of completion as meticulously recorded on drafts by Larkin, forever the careful librarian. Though this arrangement does away with the order Larkin came up with for each of his three major collections, it's also what makes this book a lively and fascinating education rather than just another somber anthology of great works glued together for profit and posterity. In fact, one can't help but feel that Larkin would have wanted it so, if only because of the complete lack of pretension and literary posturing that characterizes so much of his work. As a librarian, he was surely a man who appreciated the importance of records; as a poet, and as sad, dour, and cantankerous as his poems can be, it's also clear that he felt the only real defenses against chaos and dissolution were order and clarity, and that only through them could one hope to attain even a glimmer of understanding. Thwaite is to be commended not only for the insight he sheds on Larkin's entire career, but also for the integrity he lends to the art itself by illustrating so clearly the conviction, patience, and flat out nerve mustered by this unique poet, and how necessary such qualities are to anyone attempting a foothold on the slope of Parnassus.

Philip Larkin. Collected Poems, edited by Anthony Thwaite. Farrar, Straus, Giroux and The Marvell Press, 1989. 330 pp. $\$ 22.50$ (cloth). 
The one deviation Thwaite makes in chronology is to hold Larkin's early work from 1938 to 1945 for a second section at the back of the book, placing the major work from 1946 to 1983 at the front. Yet this, too, makes for a wonderful perspective. Only after we read the whole way through, digesting each turn in Larkin's development and then retracing the first steps he made towards his mature voice, do we discover the intimate moment of the book's first poem when, in February 1946, Larkin writes "Going" and strikes the mother lode:

There is an evening coming in

Across the fields, one never seen before,

That lights no lamps.

Silken it seems at a distance, yet

When it is drawn up over the knees and breast

It brings no comfort.

Where has the tree gone, that locked

Earth to the sky? What is under my hands,

That I cannot feel?

What loads my hands down?

Eventually collected in The Less Deceived, Larkin's second book and the one that brought him instant reknown in 1955, "Going" represents the one true voice that Larkin found as his own and from which he never turned away in the material he chose to make public for the rest of his writing life. Furthermore, "voice" is indeed the quality that most characterizes "Going" and Larkin's achievement as a whole. The hesitant sadness, the weight of evening, "one never seen before" and containing "no comfort," as well as the spare stoicism that "lights no lamps"; beyond the smooth granite polish of his craft, the sense that Larkin's poems convey of a voice speaking into empty air over great distances remains the most distinctive note of his verse. As private and mysterious a man as he still seems to us, the true mark of his poems has always been their ability to convince us of the personality behind them. At no time, however, are they simply confessional, for Larkin is hardly one to wear his heart on his sleeve. In- 
stead, the intimacy inherent to a question like "What loads my hands down?" rises above mere personal angst because of the poet's ability to mix wonder with detachment, let the moment strike a simple chord, and let it resonate for us all in a timeless realm devoid of a limiting sense of place.

To appreciate the quality of the voice Larkin eventually stumbled upon, one only has to turn to the first poem of the second section, "Winter Nocturne," to see just how far the poet traveled in his years of apprenticeship:

Mantled in grey, the dusk steals slowly in,

Crossing the dead, dull fields, with footsteps cold.

The rain drips drearily; night's fingers spin

A web of drifting mist o'er wood and wold,

As quiet as death. The sky is silent too,

Hard as granite and as fixed as fate.

The pale pond stands; ringed round with rushes few

And draped with leaning trees, it seems to wait

But for the coming of winter night

Of deep December; blowing o'er the graves

Of faded summers, swift the wind in flight

Ripples its silent face with lapping waves.

The rain falls still: bowing, the woods bemoan;

Dark night creeps in, and leaves the world alone.

Written in 1938 at the tender age of fifteen, the poem is remarkable for how closely it resembles "Going" in its content and yet remains light years from it in diction and handling. Given its unmistakable mark as juvenalia, there should be no surprise in this, yet what is interesting is the way in which small snatches of the mature Larkin exist within it as if in embryo form. Phrases like "Mantled in grey," "dull fields," "The pale pond stands," and something in the cadence of "Dark night creeps in, and leaves the world alone," its swift escape; these moments echo the poet that finds his particular jaunt and step nearly a decade later.

But as with any young poet, first must come the homage paid to the master through imitation. For Larkin, a student at Oxford himself, the first poet to grip his interest for an extended period was Auden. By 1940 he is writing almost exclusively in the same vein of intelligence and wit as his elder countryman, even going so far as to use the first line of a poem as its title, such as here in "Nothing significant was really said": 
Nothing significant was really said, Though all agreed the talk superb, and that The brilliant freshman with his subtle thought Deserved the praise he won from every side. All but one declared his future great, His present sure and happy; they that stayed Behind, among the ashes, were all stirred By memory of his words, as sharp as grit.

The one had watched the talk: remembered how He'd found the genius crying when alone; Recalled his words: 'O what unlucky streak Twisting inside me, made me break the line? What was the rock my gliding childhood struck, And what bright unreal path has led me here?'

Despite the chattiness and fascination with unhappiness and neuroses that can easily be attributed to Auden's influence, what remains unclear is whether the portrait given is one conjured as a result of imitation, or if indeed it speaks accurately of Larkin's own experience. Obviously it is some mixture of both, however impossible it may be to tell the proportions. Yet in a strange way, if we are at all tempted to read into the poem dire loneliness or fear of failure on the part of the young Larkin, much more interesting is how such temptations are refuted by the mature work and its bald, if not ribald, handling of misery and despair. Larkin's most famous example of this approach is, of course, "This Be The Verse" with its manic bark of an opening line, "They fuck you up, your mum and dad," eventually culminating in a depth charge of bitterness with the last stanza:

Man hands on misery to man.

It deepens like a coastal shelf.

Get out as early as you can,

And don't have any kids yourself.

The great difference here, however, is that the voice is so overdone, so outlandish in its dismissal, that two results are achieved. Whereas in "Nothing significant was really said" we have a sense of social commen- 
tary which hints at a direction inward but never really decides between the two, "This Be The Verse," even in its title, is so archly wry as to be hilarious and decidedly sad at the same time. In fact, the two extremes the poem stretches toward are in essence so far apart that they end up circling back to meet and cross. Sad the man who can be so humorously black about the cyclical despair of generations; how possibly well adjusted and content the man who can take such continued despair and make it buoyant and funny.

What Larkin did gain from Auden was an unblinking gaze at the world around him and the ability to accept it for what it is without swooning over a lost Eden. Here is the opening of "New Year Poem," written on the last day of 1940, England and Larkin's native town of Coventry already having experienced the ravages of the German bombs:

The short afternoon ends, and the year is over;

Above trees at the end of the garden the sky is unchanged,

An endless sky; and the wet streets, as ever,

Between standing houses are empty and unchallenged.

From roads where men go home I walk apart

- The buses bearing their loads away from works,

Through the dusk the bicycles coming home from bricks-

There evening like a derelict lorry is alone and mute.

The catalogue of decay and weariness clearly owes allegiance to Auden's own journalism of despair in "September 1, 1939," a phrase like "The short afternoon ends" sounding like a direct echo of "I sit in one of the dives. ..." Furthermore, to observe "bicycles coming home from bricks" shows a mastering of Auden's ability to take a normal human action and make it surreal by extracting the human figure and letting the objects do the work as if they have a will of their own. Finally, to encapsulate the aura of fatigue in the image of "There evening like a derelict lorry is alone and mute" proves the convincing stroke. Though we are told by Larkin that "I walk apart," we hardly need to be informed. He has so thoroughly accomplished the sense of detachment found in the early Auden that the stanza evokes a much deeper alienation through its descriptive slant than even direct statement can convey.

In the poem's second stanza, however, the role of apprentice begins to 
pay off in an altogether different manner, the shop boy having achieved such a skilled handling of the foreman's tools that they begin to take on a life of their own:

These houses are deserted, felt over smashed windows, No milk on the step, a note pinned to the door Telling of departure: only shadows

Move when in the day the sun is seen for an hour,

Yet to me this decaying landscape has its uses:

To make me remember, who am always inclined to forget, That there is always a changing at the root, And a real world in which time really passes.

Though Auden's river still runs deep through this stanza, two brief, fleeting passages stand out as bridges to the later Larkin, namely "This decaying landscape has its uses" and "a real world in which time really passes." Each passage not only retraces Auden, but also, to a larger degree, moves ahead to the later Larkin who explores the same themes in such major works as "The Whitsun Weddings" and "Church Going."

Consider, for instance, that first phrase, "this decaying landscape has its uses," and this from the latter half of "The Whitsun Weddings," the frowsy wedding parties loading themselves onto the train where Larkin observes:

All down the line

Fresh couples climbed aboard: the rest stood round;

The last confetti and advice were thrown, And, as we moved, each face seemed to define Just what it saw departing: children frowned At something dull; fathers had never known

Success so huge and wholly farcical;

The women shared

The secret like a happy funeral;

While girls, gripping their handbags tighter, stared

At a religious wounding. Free at last,

And loaded with the sum of all they saw, 
We hurried towards London, shuffling gouts of steam.

Now fields were building-plots, and poplars cast

Long shadows over major roads, and for

Some fifty minutes, that in time would seem

Just long enough to settle hats and say

I nearly died,

A dozen marriages got under way.

They watched the landscape, sitting side by side

- An Odeon went past, a cooling tower,

And someone running up to bowl-and none

Thought of the others they would never meet

Or how their lives would all contain this hour.

How prescient the earlier observation comes to seem, for here as in much of his work Larkin mines the mundane, raggedy essence of everyday life without trying to alter it in any way. Instead, it is always for him "a real world in which time really passes," not to be lectured, scolded, or even idealized, but simply taken in, tallied, mused about from an immediate post. Larkin's knack for a kind of timeless perspective occurs only within the limits of his ability to wonder as a man directly engaged with such things as a "serious house on serious earth" in a poem like "Church Going," where even an extended passage seemingly bent on assertion demonstrates the poet's own humility by ending with a question mark:

I wonder who

Will be the last, the very last, to seek

This place for what it was; one of the crew

That tap and jot and know what rood-lofts were?

Some ruin-bibber, randy for antique,

Or Christmas-addict, counting on a whiff

Of gown-and-bands and organ-pipes and myrrh?

Or will he be my representative,

Bored, uninformed, knowing the ghostly silt

Dispersed, yet tending to this cross of ground

Through suburb scrub because it held unspilt 
So long and equably what since is found Only in separation-marriage, and birth, And death, and thoughts of these-for which was built This special shell?

Nonetheless, "New Year Poem" quickly returns to an Audenesque voice in sweeping lines about "The Eden that all wish to recreate / Out of their living ....," just as Larkin would continue in the same vein for nearly three years. By 1943, however, Yeats becomes the dominate echo as a result of a lecture given by Vernon Watkins in the spring of that year at Oxford. Larkin's first book, The North Ship, published in 1944, is rife with echoes of Yeats; so much so that it is difficult to cull even a hint of the poet Larkin would become. Still, what Larkin gained from Yeats was an education in the workings of the well-made lyric, especially as produced by the great Irishman in his early and middle years. Here, for instance, is Larkin's "Pour away that youth" in its entirety:

Pour away that youth

That overflows the heart

Into hair and mouth;

Take the grave's part,

Tell the bone's truth.

Throw away that youth

That jewel in the head

That bronze in the breath;

Walk with the dead

For fear of death.

No matter how Yeatsian, no matter how false the voice may sound here, the poem does demonstrate a real sense of control. Full of the myth and magic Yeats would apply to tropes such as "the grave's part," "the bone's truth," "That jewel in the head / That bronze in the breath," the poem as a whole, however, does not ask to be altered in order to be improved, but rather in its compression and resonance it fulfills all of the expectations set out by the voice that guides it. In fact, only our knowledge of the mature Larkin leads us to reject it so quickly as merely imitative, for at the time of 
its writing it must have sounded impressive to anyone with a passion for Yeats.

Though quite similar to what Larkin learned from Yeats, a slightly different sense of control provides the pleasure of the short lyrics that make up such a large part of the mature work. "Cut Grass," written in 1971, demonstates how, many years later, Larkin still makes use of Yeatsian cadence, yet for an altogether different effect:

Cut grass lies frail:

Brief is the breath

Mown stalks exhale.

Long, long the death

It dies in the white hours

Of young-leafed June

With chestnut flowers,

With hedges snowlike strewn,

White lilac bowed,

Lost lanes of Queen Anne's lace,

And that high-builded cloud

Moving at summer's pace.

Right up until the last stanza Larkin could as well be writing "Pour away that youth," phrases such as "brief is the breath," "Long, long the death," and "hedges snowlike strewn" sounding as abstract and portentous as the earlier poem. But where the first builds its argument in mythic fashion through the mounting rhymes of "youth / truth / breath / death," the latter undercuts its own rising motion through the simple description of "White lilac bowed, / Lost lanes of Queen Anne's lace," the cadence itself doing the trick rather than the poet's heavy hand. Similarly, it's the unexpected expanse, the turn made in the last two lines of "that high-builded cloud / Moving at summer's pace," which indicates Larkin's true signature. Suddenly we are carried altogether elsewhere in the poem, the implications of the fact that "Cut grass lies frail" now made readily apparent, just as the melancholy of the poet behind the lines is made as immediate and fleeting as the clouds themselves. Unlike the earlier poem where 
Larkin is sweating to capture the weighty note of the classical lyric which Yeats carried into modern verse, in "Cut Grass" he simply relies on a faint echo of that note to structure the poem while also allowing his own descriptive powers to lend it a sense of the personal. After Yeats, it was Thomas Hardy who led Larkin to such tactics. Yeats was fine as a mentor of control and poem making, but Larkin gained from Hardy a sense of the sad and unreal within the real, rather than in a mythic realm beyond it. Hence, after "Going," what we have is a classical poet turned living commentator, the subject matter being the tawdry life around him of work and home and post-war boredom; the note struck within it one of sadness and acceptance, at times mixed with flashes of black humor, but always the personal voice and view, "the evening coming in."

But what of the "secret" Larkin? What about the sixty-one poems from the mature poet which Thwaite has collected here for the first time? How much did Larkin keep hidden, and can it be true that, despite the general silence of his pen after the publication of High Windows in 1974, dozens of fine poems lay hidden in his desk drawer waiting to be collected and shared with the world?

Disappointment is such a central theme to Larkin's work that it should come as no surprise to find that, indeed, after High Windows the poet's pen essentially ran dry for the last decade of his life. Only seven poems from those silent years appear here for the first time, none of them any more profound than the work already achieved, the vast calm that surrounds them seeming even more poignant than the poems themselves. Eight other "occasional" pieces also exist from these years, most of them dedicated to colleagues and fellow poets, but what the overall output demonstrates is that Larkin found himself unable to write about anything in his last years except the deeply personal or what was safely distanced by a public role.

"Love Again," from 1979, is a good example of the personal note in these unpublished poems, though as ever Larkin's voice remains that of a constructed persona more than the man himself:

Love again: wanking at ten past three (Surely he's taken her home by now?), The bedroom hot as a bakery,

The drink gone dead, without showing how 
To meet tomorrow, and afterwards, And the usual pain, like dysentery.

Someone else feeling her breasts and cunt, Someone else drowned in that lash-wide stare, And me supposed to be ignorant, Or find it funny, or not to care, Even . . . but why put it into words? Isolate rather this element

That spreads through other lives like a tree And sways them in a sort of sense And say why it never worked for me. Something to do with violence A long way back, and wrong rewards, And arrogant eternity.

Once again we have the crass curmudgeon of "This Be The Verse," though by now the hilarity seems to have gone out of the voice, a tinge of real bitterness having crept in. Similarly, it's as if Larkin checks himself by questioning the stance normally taken, one where he is "supposed to be ignorant, / Or find it funny, or not to care." Instead, having so thoroughly constructed the role he has played for years, now he is reduced to asking “. . . but why put it into words?" matters grown less funny, though no less poignant, "arrogant eternity" holding sway over the poet's final years much like the "evening coming in" that had haunted his work for so long.

This kind of turn toward reticence is, of course, one of the central joys of Larkin's work. Within it lies an integrity, a patience which makes so many of his poems seem acts of necessity rather than somersaults performed for literary fame. What's more, if there is a central theme running throughout all of Larkin it would have to be that of love and the difficulty of attaining satisfaction within it. "Love Again," coming at the end of the career, not only shows this recurrence, it also bears witness to the sadness of having to face such difficulty again and again. The key difference in this stage of Larkin's career, however, is that out of such resignation comes only silence, or at best the veiled intimacy of a poem like "The little lives 
of earth and form," written in 1977 on the flyleaf of a book of mammals and, according to Thwaite, dedicated in longhand "To Monica with all love from Philip":

The little lives of earth and form, Of finding food, and keeping warm,

Are not like ours, and yet

A kinship lingers nonetheless:

We hanker for the homeliness

Of den, and hole, and set.

And this identity we feel

- Perhaps not right, perhaps not real-

Will link us constantly;

I see the rock, the clay, the chalk,

The flattened grass, the swaying stalk, and it is you I see.

Given the particularly un-Larkian moment of the poem, we will have to wait for biography to sort out the context from which it springs, just as there is still so much to be learned about Larkin's life as a whole. In the meantime, suffice it to say that Larkin remains a paradox as a poet. Though he seems to have been a poet concerned with the nature of love above all else, it's a concern that manifests itself only in the guise of doubt and failure in the face of love, the "identity we feel" remaining genuinely there, yet swept under and away by the prevailing reticence that thinks it nonetheless "Perhaps not right, perhaps not real," no matter how deeply felt.

Yet such skepticism and wariness is also a large part of why we turn to Larkin as a poet who published little if anything that is not remarkable. The three slim volumes, the decade that separates each of them, the reluctance of the poet to give readings or interviews; all of it contributed to the aura that surrounded Larkin as a writer concerned only with the making of good poems. Thwaite's gathering does nothing to dispell this aura, for in fact the most wonderful aspect of reading through the Collected is to discover the kind of standard Larkin set for himself, as well as the skepticism he brought to his own work. Here, for instance, is "An April Sunday 
brings the snow," written in 1948 and, amazingly enough, held back from publication until now:

An April Sunday brings the snow

Making the blossom on the plum trees green,

Not white. An hour or two, and it will go.

Strange that I spend that hour moving between

Cupboard and cupboard, shifting the store

Of jam you made of fruit from these same trees:

Five loads - a hundred pounds or more-

More than enough for all next summer's teas,

Which now you will not sit and eat.

Behind the glass, under the cellophane,

Remains your final summer - sweet

And meaningless, and not to come again.

Too personal? Too incidental? Lacking severity in its vision? One would be hard pressed to figure out just why Larkin never saw fit to publish a poem as lovely as this. Biography, again, may provide the key as to why the poet felt so reluctant, though one can also guess that after having written "Going" in 1946, Larkin realized how distinct his voice had become from all he had written before and that it would be wise to remain on the watch for false notes. The most convincing argument, though, would seem to be that the poet was as severe with himself as he was in his vision. "Compline," written in 1950, demonstrates just this:

Behind the radio's altarlight

The hurried talk to God goes on:

Thy Kingdom come, Thy will be done,

Produce our lives beyond this night,

Open our eyes again to sun.

Unhindered in the dingy wards

Lives flicker out, one here, one there,

To send some weeping down the stair 
With love unused, in unsaid words:

For this I would have quenched the prayer,

But for the thought that nature spawns

A million eggs to make one fish.

Better that endless notes beseech

As many nights, as many dawns,

If finally God grants the wish.

Once again a fine effort on the part of a young poet just having found his proper gait in writing. "Lives" that "flicker out, one here, one there," the "love unused, in unsaid words"; it all seems quintessential Larkin, except maybe the urge that "finally God grants the wish," such positive reverence being a little out of place with the skeptic we would come to know. Even this, however, seems hardly enough to strike the poem from the record or not to publish it in journal form. Why then the hook?

To experience the answer one needs only to look to either side of "Compline" and see key events in Larkin's writing life at the time. Five weeks before it he writes "At Grass" and just eight days after it he completes "Deceptions," two of his most lasting poems, each of which makes "Compline" look mild. In the first, for instance, there is that lovely ending and the description of the horses at dusk:

Do memories plague their ears like flies?

They shake their heads. Dusk brims the shadows.

Summer by summer all stole away,

The starting-gates, the crowds and cries-

All but the unmolesting meadows.

Almanacked, their names live; they

Have slipped their names, and stand at ease,

Or gallop for what must be joy,

And not a fieldglass sees them home,

Or curious stop-watch prophesies:

Only the groom, and the groom's boy,

With bridles in the evening come. 
Meanwhile, nothing in "Compline" could even hope to match the description Larkin gives in "Deceptions" of a nineteenth-century woman violated and seduced, and how her "Mind lay open like a drawer of knives," the poet deftly demonstrating his compassion when he states:

Slums, years, have buried you. I would not dare Console you if I could. What can be said, Except that suffering is exact, but where

Desire takes charge, readings will grow erratic?

For you would hardly care

That you were less deceived, out on that bed, Than he was, stumbling up the breathless stair To burst into fulfilment's desolate attic.

In short, given the achievement of poems like these, it's as if Larkin could not remain satisfied with something as safe as "Compline," the sentiment that rejected it very much the same one that asks ". . . but why put it into words?"

And it is this kind of discerning eye and hand that we experience throughout the Collected. Not always does Larkin seem to make the right choice, for there are a few poems which seem so utterly fine as to cause real excitement when reading them now. "Far Out," written in 1959, is just such a poem, its skepticism and the turn at the end as good as the best of Larkin:

Beyond the bright cartoons

Are darker spaces where

Small cloudy nests of stars

Seem to float on the air.

These have no proper names:

Men out alone at night

Never look up at them

For guidance or delight,

For such evasive dust

Can make so little clear: 
Much less is known than not, More far than near.

On the whole, however, the Larkin that we have in the three major collections is the same poet who will remain with us. Witty, sad, lugubrious, musing, compassionate, "bored" and "uninformed"; the voice that speaks at the heart of poems such as "Church Going," "An Arundel Tomb," "Going," "At Grass," "Toads," "Water," "High Windows," "Reasons for Attendance," "Sad Steps," and so many others, this is the voice that readers will continue to turn to, not for the sake of joyful wonder or pyrotechnics of the soul, but rather for that same clear insight that pervades the work, the "sun-comprehending glass" of "High Windows," poem and poet alike forever suspended between the poles of affirmation and doubt, the unspoken wisdom of the less deceived,

And beyond it, the deep blue air, that shows

Nothing, and is nowhere, and is endless.

That there is no real "news" in Larkin's Collected Poems should come as no surprise, for he was hardly a poet concerned with playing games with either his career or his work. Instead, it's easy to think of Larkin as a trusted companion, his poems having that rare quality, memorableness, which helps to lodge them inside one's life like books upon the shelf, ordered and alive, simply waiting to be taken down again and enjoyed. Here, as a result of Thwaite's fine editing, we have the added joy of watching the choices mulled over, the decisions made by a strange, sad man who seems to have found himself always on the outside of life and love, though drawn for "a moment to the lighted glass / To watch the dancers," as in "Reasons for Attendance," only to discover once again that

What calls me is that lifted, rough-tongued bell (Art, if you like) whose individual sound Insists I too am individual. 